\title{
Funkcje żlobków polskich od początku XX wieku do wybuchu II wojny światowej
}

\begin{abstract}
Polish nurseries from the early $20^{\text {th }}$ century to the beginning of World War II
The issue of institutional care of the youngest children has been rarely discussed in scientific studies. In the context of the contemporary debates about improving the quality of toddlers' care and education, it is a good idea to remind about the origin of nurseries and the development thereof. The first nurseries were established in Poland over 100 years ago. From the beginning, before Poland even regained independence until present day, they have changed their functions and organization. The aim of the article is to show the changes to the function of crèches against a political, social and cultural background since the very beginning of the existence of nurseries until the outbreak of World War II. The method used in this article is historical explanation, and the technique is an analysis of documents: literature, magazines, legal acts. The responsibilities of crèches discussed in this article include care, health -related, educational, upbringing and family-related activities This is the first of two articles related to changes in the function of crèches in a historical approach.
\end{abstract}

Keywords: nurseries, toddlers care and education, infant

\section{Wstęp}

Problematyka instytucjonalnej opieki nad najmłodszymi dziećmi jest rzadko podejmowanym zagadnieniem w opracowaniach naukowych. W kontekście współczesnych debat nad poprawą jakości opieki, wychowania i edukacji dzieci w wieku poniemowlęcym warto przypomnieć genezę żłobków i rozwój ich funkcji od początków ich istnienia. Żłobek obok klubu dziecięcego to instytucja opiekuńcza przeznaczona dla najmłodszych dzieci. Obecnie mogą w niej przebywać dzieci od 20. tygodnia życia do ukończenia trzeciego roku życia w roku szkolnym, w którym dziecko ukończy trzy 
lata ${ }^{1}$. Na przestrzeni ponad 100 lat istnienia dziennych instytucji opieki nad niemowlęciem małym dzieckiem pod wpływem różnych czynników związanych z przemianami kulturowo-społecznymi oraz uprzemysłowieniem środowiska życia człowieka ich funkcje się zmianiały. Celem artykułu jest ukazanie funkcji żłobków na tle zmian, jakim ulegały one od początku XX w. do wybuchu II wojny światowej. Problem główny artykułu został sformułowany następująco: Jakie można wyróżnić funkcje żłobków w ich historii mające na celu poprawę różnych obszarów funkcjonowania rodzin? Sformułowano również problemy szczegółowe: Jak zmieniały się funkcje żłobków przed odzyskaniem przez Polskę niepodległości i w okresie międzywojnia? Które z wyróżnionych funkcji żłobków były realizowane w większym, a które w mniejszym stopniu w omawianych okresach historycznych? Jakie czynniki mogły mieć związek ze zmianami funkcji żłobków w omawianym okresie?

Na potrzeby artykułu zostały przeprowadzone badania metodą wyjaśniania historycznego ${ }^{2}$. W pracy badawczej posłużono się techniką analizy dokumentów, tj. literatury przedmiotu, czasopism z omawianego okresu oraz aktów prawnych związanych z funkcjonowaniem żłobków.

\section{Funkcje żłobków}

Według Stownika Języka Polskiego funkcja to zadanie, które spełnia lub ma spełnić jakaś osoba lub rzecz ${ }^{3}$, zatem funkcje żłobka można określić jako zadania, jakie spełnia żłobek wobec swoich podopiecznych i ich rodzin lub jako cele, do których zmierza działalność żłobka. Na potrzeby artykułu wyróżniono dwa rodzaje funkcji, które może spełniać żłobek. Pierwszy rodzaj to funkcje instytucjonalne, które charakterystyczne są np. dla placówek edukacyjnych czy medycznych. Drugi rodzaj to funkcje osobowe, charakterystyczne dla grup nieformalnych, np. rodziny, do której współczesny żłobek chciałby się niejako zbliżyć. Poniżej zostaną one opisane.

Pierwsza z funkcji instytucjonalnych - opiekuńcza - związana jest z zapewnieniem opieki fizycznej dla dzieci, a w historii żłobków może łączyć się również z walką z ubóstwem i marginalizacją społeczną małych dzieci i matek pracujących w miastach przemysłowych. Powyższa funkcja łączy się z funkcją prozawodową, która umożliwia rodzicom dzieci uczęszczających do placówek pracę zawodową oraz może przyczynić się do ich rozwoju osobistego. Kolejna funkcja - prozdrowotna - łączy się z zapobieganiem chorobom dziecięcym, walką ze śmiertelnością niemowląt i dzieci, promocją higieny i czystości, promocją zdrowego żywienia i karmienia piersią. Funkcja wychowawcza to przede wszystkim przyswojenie zasad panujących w grupie i ogólnie wstępna socjalizacja

\footnotetext{
${ }^{1}$ Ustawa z dnia 4 lutego 2011 r. o opiece nad dziećmi wieku do lat trzech, Dz.U. 2011, nr 45, poz. 235.

2 J. Topolski, Metodologia historii, PWN 1984, s. 445.

${ }^{3}$ L. Drabik, E. Sobol, Stownik języka polskiego. A-Q, PWN, Warszawa 2007, s. 186.
} 
małych dzieci. Zadaniem funkcji edukacyjnej (inaczej można ją nazwać funkcją prorozwojową) jest wspomaganie rozwoju dziecka w poszczególnych jego obszarach, głównie poprzez zabawę i zajęcia dostosowane do potrzeb małych dzieci. Żłobki powinny też spełniać funkcje osobowe, których celem jest tak jak w rodzinie zaspokajanie potrzeb emocjonalnych, potrzeb intymnego współżycia, równowagi emocjonalną ${ }^{4}$. Wyrazem nastawienia na tego typu potrzeby może być na przykład współpraca rodziców z personelem żłobka.

\section{Funkcje i zadania pierwszych żłobków do wybuchu I wojny światowej}

Pierwsze żłobki na terenie Królestwa Polskiego powstały pod koniec XIX w., jednak ich pozycja i rola w opiece społecznej była marginalna. Do ich powstania przyczyniła się możliwość podjęcia pracy w powstających na teranie dużych miast zakładach przemysłowych oraz związana z tym konieczność zapewnienia opieki niemowlętom i małym dzieciom na czas pracy rodziców, zwłaszcza kobiet. Część osób z powodu trudnych warunków materialnych zmuszonych zostało do migracji ze wsi do miast i życia oraz pracy w oderwaniu od rodziny pochodzenia, bez możliwości wsparcia dalszej rodziny czy sąsiadów, stąd opieka nad ich dziećmi stała się pilną potrzebą społeczną. W najuboższych rodzinach matki niedługo po porodzie musiały wrócić do pracy zawodowej, dlatego publicyści i działacze społeczni na terenie Królestwa Polskiego podkreślali potrzebę zapewnienia społecznego wsparcia ubogim rodzinom oraz samotnym matkom, zwłaszcza wychowującym niemowlęta i małe dzieci ${ }^{5}$. Polacy pozbawieni państwowości zwracali szczególną uwagę na wychowanie młodego pokolenia, jego kondycję fizyczną i edukację, tymczasem narastał problem pozostawiania dzieci bez opieki na czas pracy rodziców, często w bardzo niehigienicznych warunkach ${ }^{6}$. Zwracano uwagę, że brak właściwej opieki był przyczyną wysokiej umieralności dzieci do trzeciego roku życia, obok złych warunków bytowych i pożywienia marnej jakości oraz niemożności walki z chorobami zakaźnymi ${ }^{7}$. Już wtedy widziano potrzebę tworzenia dziennych instytucji opiekuńczych, w których oprócz zapewnienia opieki niemowlętom i dzieciom można by zapobiegać chorobom i kontrolować stan ich zdrowia:

Żłobki dla małych dzieci powinnyby zostać otwarte we wszystkich bez wyjątku dzielnicach miasta, nie są one bowiem przeznaczone dla najuboższych, ale dla tej licznej klasy szwaczek,

${ }^{4}$ F. Adamski, Rodzina. Funkcje rodziny, w: Encyklopedia pedagogiczna XXI wieku, red. T. Pilch, Wyd. Akademickie „Żak” Warszawa 2006, s. 309.

5 S. Markiewicz, Sprawa dzieci opuszczonych, „Ateneum” 1890, nr 6, t. II, s. 416-417.

${ }^{6}$ W. Kon, Walka ze śmiertelnościa niemowląt $w$ Lodzi, „Zdrowie” 1906, nr 11, s. 744-745.

${ }^{7}$ A. Bołdyrew, Żłobki i stacje „Kropla Mleka” jako placówki wspierające ubogie rodziny w Królestwie Polskim na przetomie XIX i XX wieku, ,Wychowanie w Rodzinie” 2016, t. XIV, z. 2, s. 108. 
praczek itp., które spędzają dni za domem, służących trzymać nie mogą, a nie mają nikogo w rodzinie, kto mógłby czuwać nad dzieckiem ${ }^{8}$.

Aneta Bołdyrew podkreśla, że w literaturze głównie skupiano się na tym, by placówki takie zapewniały opiekę fizyczną i pielęgnacyjną, natomiast pomijano pedagogiczne aspekty ich działalności”’. Oznacza to, że pierwsze żłobki pełniły głównie funkcje opiekuńcze i prozawodowe. Z badań A. Bołdyrew wynika, że pierwsze żłobki na terenie Królestwa Polskiego działały w Warszawie w drugiej połowie XIX w., mieściły się one ul. Browarnej, Złotej, Dzielnej. Żłobki te działały przez kilka lat, potem zaś były zamykane z powodu zbyt małej liczby dzieci ${ }^{10}$. Do czasu odzyskania przez Polskę niepodległości tworzenie żłobków i ich prowadzenie nie było w żaden sposób uregulowane prawnie, były one tworzone przez prywatne osoby lub Towarzystwa Dobroczynności. Do ich głównych funkcjami zaliczały się: przeciwdziałanie marginalizacji społecznej kobiet $\mathrm{i}$ ich dzieci poprzez zapewnienie minimum opieki niemowlętom, których matki znajdowały się w trudnej sytuacji. Były to przykładowo matki samotne, ubogie, niewydolne wychowawczo, oraz te, które musiały podjąć pracę zawodową. Realizacja założonych funkcji nie była zadowalająca; szerzące się choroby, brak wykwalifikowanej kardy, brak wiedzy o rozwoju i funkcjonowaniu małych dzieci oraz oderwanie dzieci od matek we wczesnym wieku przyczyniało się do dużej śmiertelności dzieci w tych placówkach.

\section{Funkcje żłobków w dwudziestoleciu międzywojennym}

Po odzyskaniu przez Polskę niepodległości problem opieki nad małymi dziećmi powrócił ze zwiększoną siłą. Nadal borykano się z dużą śmiertelnością niemowląt i brakiem opieki nad dziećmi robotnic z miast uprzemysłowionych ${ }^{11}$. Przykładowo Łódź była miastem, w których odsetek śmiertelności niemowląt przed II wojną światową był największy.

Kiedy w 1937 r. wskaźnik śmiertelności niemowląt wynosił dla całego kraju 13-14\%, to dla Łodzi - miasta robotnic fabrycznych - wynosił on $17-18 \%$, w odniesieniu do całego miasta, a był z pewnością wyższy dla dzielnic robotniczych. [...] Dzielnice robotnicze wykazywały największą śmiertelność niemowląt, wielokrotnie przewyższającą śmiertelność niemowląt dzielnic zamieszkanych przez ludność zamożniejszą ${ }^{12}$.

${ }^{8}$ Jeszcze o losach opuszczonych dzieci, „Kronika rodzinna” 1891, nr 22, s. 677.

9 A. Bołdyrew, op. cit., s. 105-106.

${ }^{10}$ Ibidem, s. 110-111.

11 J. Bogdanowicz, Żłobki fabryczne dla niemowląt, „Opieka nad dzieckiem” 1927, nr 1, s. 23; Z. Garlicka, Żłobki dzienne dla niemowląt matek pracujących, Drukarnia SIŁA, Warszawa 1927.

12 Z. Golde, Żłobek. Organizacja i prowadzenie, PZWL, Warszawa 1956, s. 7. 
Z badań Zofii Garlickiej wynika, że dzieci robotnic pozostawione podczas pracy matek bez należytej opieki, niemowlęta od pierwszych tygodni życia karmione sztucznie często zapadały na różne schorzenia i ginęły. Największy odsetek zgonów niemowląt autorka stwierdziła $\mathrm{w}$ grupie dzieci, których matki krótko po porodzie, tj. przed 10. tygodniem życia dziecka, wróciły do pracy ${ }^{13}$.

Piśmienna część społeczeństwa była świadoma problemów matek pracujących. Przykładowo w prasie przeznaczonej dla kobiet pisano:

Nigdy matka i dziecko, zwłaszcza w środowisku niezamożnem, nie wymagało tyle pomocy od społeczeństwa co obecnie. Ciężkie warunki ekonomiczne, a zwłaszcza bezrobocie - zmusiły matkę - aby poza swemi naturalnemi obowiązkami: opieką nad dziećmi i prowadzeniem domu - zajęła się zarobkowaniem. Niejednokrotnie, w związku z łatwiejszą nieraz sposobnością zarobkowania przez matkę - ta ostatnia cały czas spędza poza domem, na posługach w fabryce - bezrobotny zaś ojciec bawi dzieci i zajmuje się kuchnią. Jakkolwiek mężczyzna nie zawsze wywiązuje się pomyślnie z nowych dla niego obowiązków, w każdym razie dzieci otrzymują jaką taką opiekę w czasie nieobecności matki. Gorzej jest jednak, gdy tej opieki brak, matka wdowa czy matka nieślubna zmuszona jest pozostawiać dzieci, albo bez opieki, albo na łasce najstarszego dziecka, albo mało przychylnej, często złej i dokuczliwej sąsiadki. Że dziecko jest bardziej niezaradne i bezsilne, im jest młodsze - tem skutki są fatalniejsze i prawdziwie tylko szczęśliwy zbieg wypadków pozwala mu wyjść obronną ręką z tej opresji ${ }^{14}$.

Świadomość powyższych problemów wymusiła podjęcie prac ogólnonarodowych i lokalnych mających na celu roztoczenie opieki nad dzieckiem. Partie polityczne formułowały programy, w których postulowano utworzenia osobnych zakładów opieki dla dzieci do lat czterech ${ }^{15}$. Zaczęto tworzyć instytucje opieki społecznej, starano się podnieść poziom wykształcenia tych wszystkich, którzy pośrednio czy bezpośrednio opiekę tę wykonują. Ponadto podkreślano, że trzeba zdobywać wiedzę na temat dziecka.

Zajrzyjmy - pisano - [...] do książek z dziedziny opieki nad dzieckiem, do książek, które uczą jak gotować przyszłość narodu. Załóżmy w większych przynajmniej miastach zwykłe koła samokształcenia się dla działaczy na polu opieki nad dziećmi ${ }^{16}$.

Zaczęto również zakładać żłobki i stacje opieki nad niemowlętami, których zadaniem było otoczyć dziecko właściwą opieką lekarską i społeczną ${ }^{17}$. Pierwszy żłobek w niepodległej Polsce powstał w Łodzi. Zakład ten - pisał Bronisław Knichowiecki ${ }^{18}$ :

13 Z. Garlicka, op. cit.

14 T.Z., Żłobek otwarty, „Dziecko i Matka” 1926, nr 13, s. 5-6 [brak pełnego nazwiska autora - E.Ś.].

15 M. Balcerek, Rozwój opieki nad dzieckiem w Polsce w latach 1918-1939, PWN, Warszawa 1978, s. 88-105.

16 M. Michałowicz, Kształćmy się, „Opieka nad Dzieckiem”1930, R. VIII, nr 3, s. 124.

17 J. Wnęk, Dziecko w polskiej literaturze naukowej 1918-1939, Oficyna Wydawnicza ASPRA-JR, Warszawa 2012, s. 250; B. Knichowiecki, Pierwszy Miejski Dom Wychowawczy dla niemowlat w Łodzi, „Opieka nad Dzieckiem” 1931, nr 5, s. 217-228.

18 B. Knichowiecki, op. cit, s. 217. 
rozwinął się z małego, bo zaledwie na 15-20 niemowląt obliczonego ,żłobka”, mieszczącego się pierwotnie w domu przy ul. Nawrot 58 założonego w r. 1915 przez Tow. Schronisk św. Stanisława Kostki [...]. Ciasnota pomieszczenia, stałe przepełnienie, brak wykwalifikowanej kadry pielęgniarskiej, brak bielizny, to wszystko sprzyjało śmiertelności niemowląt, która wtedy wynosiła 99\% [...]. Do roku 1922 zmodyfikowano funkcjonowanie żłobka, przeniesiono go do trzypiętrowej kamiennicy, dostarczono bieliznę, zaangażowano mamki. W zakładzie pracowało 2 lekarzy, 9 sióstr, 5 służących i 26 mamek. Przyjmowane były dzieci od urodzenia do 1,5 roku, również podrzutki ${ }^{19}$.

Autor relacjonował:

Śmiertelność w naszych zakładach jest zależna w znacznej mierze od stanu zdrowia dzieci w chwili ich przyjęcia. Podrzutki, dzieci ulicy, z dołów biologicznych, dzieci matek nieślubnych, bezdomnych są kierowane do nas w stanie beznadziejnie ciężkim, częstokroć umierają one już w pierwszej dobie swego pobytu w zakładzie ${ }^{20}$.

Pierwszy żłobek w Warszawie powstał w 1924 r. przy ulicy Puławskiej 33 (Mokotów). Mógł przyjąć 20 niemowląt.

Codziennie rano (6 rano) matki, idąc do pracy pozostawiają dzieci personelowi żłobka, aby wieczorem (6 wieczór) zabrać je do domu. W żłobku poza opieką pielęgniarsko-lekarską (przyjmowane są tylko zdrowe dzieci) dzieci dostają jeść, przyczem te matki, które karmią, o ile pracują w pobliżu, przychodzą dziecko nakarmić piersią. Cały wysiłek personelu jest wytężony w kierunku zapewnienia dziecku opieki na miejscu (jedzenie dostosowane do wieku, kąpiel, odpowiednio przewietrzony, czysty i jasny lokal), zabezpieczenia przed infekcją, wobec obecności większej liczby dzieci (przyjmowanie przez kontrolę tylko dzieci zdrowych, osobne woreczki na ubranie domowe dzieci, numerowane łóżeczka, numerowane pieluszki i smoczki, parawany i izolacja dla podejrzanych dzieci), uzyskania wpływu na matki, aby starały się utrzymać czysto dzieci, stosowały się do wskazań pielęgniarki i lekarza i z zachowaniem odnosiły się do instytucji ${ }^{21}$.

Dalszy rozwój żłobków - ich zakładanie i prowadzenie - umożliwiło ustawodawstwo II RP. Powstały wówczas pierwsze regulacje prawne dotyczące żłobków. W 1923 r. żłobki wliczono do zakładów o charakterze opiekuńczym, a ich tworzenie i utrzymywanie powierzono gminom ${ }^{22}$. Źródłem finansowania tych instytucji było Ministerstwo Pracy i Opieki Społecznej, Wydział Opieki Społecznej przy Komitecie Rządu i Magistraty poszczególnych miast. $Z$ tego powodu żłobki w okresie dwudziestolecia międzywojennego były przeważnie bezpłatne, w miarę możliwości matki składały tam ,pewne drobne opłaty”23.

W lipcu 1924 r. ukazała się ustawa o przedmiocie pracy młodocianych i kobiet nakładająca na przedsiębiorców zatrudniających powyżej 100 kobiet obowiązek

\footnotetext{
${ }^{19}$ Ibidem.

${ }^{20}$ Ibidem, s. 222.

${ }^{21}$ T.Z., op. cit, s. 5-6.

${ }^{22}$ Ustawa z dnia 16 sierpnia 1923 roku o opiece społecznej, Dz.U. 1923, nr 92, poz. 726, art. 5.

${ }^{23}$ T.Z., op. cit., s. 5-6.
} 
prowadzenia żłobków dla niemowląt ${ }^{24}$. Prawie trzy lata później ukazało się rozporządzenie w sprawie urządzenia i utrzymania żłobków dla niemowląt w zakładach pracy ${ }^{25}$. Przepisy rozporządzenia były dość szczegółowe. Określały przykładowo, że na jedną opiekunkę może przypadać maksymalnie 30 dzieci (dziś jest to $8 \mathrm{w}$ wieku powyżej 1 roku życia lub 5 dzieci poniżej roku ${ }^{26}$ ), żłobki mogły przyjmować dzieci od 0 do 15 miesięcy, każde dziecko miało w żłobku oddzielne łóżeczko. Jednak zakładanie żłobków nie leżało w interesie ani przedsiębiorców, ani rządów sanacyjnych. Przemysłowcy i fabrykanci kategorycznie sprzeciwiali się temu zarządzeniu. Aby uchylić się od utrzymywania żłobków, używali oni różnych sposobów, fałszowali wykazy zatrudnionych kobiet, nie przyjmowali do pracy kobiet mających dzieci w wieku żłobkowym itp. ${ }^{27}$ Doktor Jan Bogdanowicz pisał w 1927 r.: „nie mamy dotąd ani jednego żłobka dla niemowląt w zakładach pracy, nawet w przedsiębiorstwach rządowych”. Autor wskazuje, że:

pracodawcy nie chcą ponosić odpowiedzialności za wypadki dzieci w żłobkach, przywożenie dzieci do pracy grozi niebezpieczeństwem związanym z podróżą w godzinach porannych i wieczornych, żłobki utrudniają karmienie piersią matkom pracującym - gdyż matki są bardzo zmęczone pracą i tracą pokarm, wreszcie utrzymanie żłobka jest dla pracodawcy dodatkowym kosztem, a matki muszą być odrywane od pracy na karmienie dzieci i zaburza to organizację pracy ${ }^{28}$.

Niemniej 3 listopada 1927 r. został uruchomiony pierwszy na terenie Rzeczypospolitej żłobek fabryczny przy Państwowej Fabryce Wyrobów Tytoniowych na ulicy Dzielnej w Warszawie ${ }^{29}$. Personel żłobka składał się z lekarki pediatry, kierowniczki, pielęgniarek i personelu niższego. Według Janiny Jaroszewskiej:

dwa razy w ciągu trwania pracy fabrycznej robotnice-matki przychodzą do żłobka, aby karmić niemowlęta. [...] Każda matka musi zostawić swój fabryczny fartuch i chustkę z głowy na parterze, przed salą zaś do karmienia na korytarzu ubrać się w fartuch biały i takiż czepek, umyć dobrze ręce i dopiero tak przygotowana ma prawo do otrzymania dziecka. [...] Na salę dzienną matki wstępu nie mają, widzą je tylko przez drzwi. Podczas karmienia na sali jest obecna dyżurna pielęgniarka, która zwraca uwagę na prawidłowe trzymanie dzieci w czasie ssania, obmywanie piersi, karmienie z jednej piersi itp., od czasu do czasu odbywają się pogadanki lub też czytanie artykułów z pism popularno-higienicznych ${ }^{30}$. art. 15 .

${ }^{24}$ Ustawa z dnia 2 lipca 1924 r. w przedmiocie pracy młodocianych i kobiet, Dz.U. 1924, nr 65, poz. 636,

25 Rozporządzenie Ministra Pracy i Opieki Społecznej z dnia 11 marca 1927 r. w sprawie urządzenia i utrzymania żłobków dla niemowląt w zakładach pracy, Dz.U. 1927, nr 32, poz. 293.

${ }^{26}$ Ustawa z dnia 4 lutego 2011 r. o opiece nad dziećmi wieku do lat trzech, Dz.U. 2011, nr 45, poz. 235.

27 Z. Golde, op. cit., s. 7.

28 J. Bogdanowicz, op. cit., s. 194.

29 J. Jaroszewska, 3 lata działalności żłobka fabrycznego przy Państwowej Fabryce Wyrobów Tytoniowych, „Opieka nad Dzieckiem” 1931, nr 7-8, s. 251-269.

30 Ibidem, s. 259. 
Do żłobków zawsze były przyjmowane tylko dzieci zdrowe, jednak już wtedy zauważano problem opieki nad dziećmi chorymi i brak możliwości zwolnienia się z pracy na czas choroby dziecka ${ }^{31}$. Po kontroli Inspekcji Pracy i stwierdzeniu uchybień w prowadzeniu i zakładaniu żłobków położono większy nacisk na realizację ustawy o przedmiocie pracy młodocianych i kobiet, co przełożyło się na większą liczbę zakładanych żłobków w różnych miastach Polski ${ }^{32}$. Przykładowo Monopol Tytoniowy w latach 1927-1929 uruchomił żłobki w Bydgoszczy, Poznaniu, Kościanie, Starogardzie, Łodzi, Radomiu, Grodnie ${ }^{33}$. We wszystkich placówkach dbano o higienę i właściwe odżywianie dzieci. Skład racji żywnościowych każdego dziecka ustalał lekarz, dzieci dostawały posiłki mleczne, zupy oraz owoce. Ponadto stosowano różne środki lecznicze oraz lampy kwarcowe w celu przeciwdziałania krzywicy niemowląt. Opieką objęto również matki robotnice, które otrzymywały bezpłatne porcje mleka - pół litra dziennie, w celu uzupełnienia braków witaminowych wynikających z karmienia dzieci ${ }^{34}$. Żłobki były również prowadzone przez Monopol Spirytusowy, niektóre zakłady wojskowe oraz Monopol Zapałczany.

Z przytoczonych materiałów wynika, że pierwsze żłobki w niepodległej Polsce miały głównie funkcję opiekuńczą i prozawodową. Ich celem było zapewnienie jak najlepszej opieki nad dziećmi podczas pracy rodziców, ponadto poprzez dbałość o higienę i odpowiednie odżywianie starano się ograniczyć śmiertelność i podatność na choroby najmłodszych. Szczepionki przeciwko chorobom zakaźnym były wówczas w fazie eksperymentalnej i, chociaż przynosiły pożądane efekty, głównym sposobem żłobków na przeciwdziałanie chorobom była promocja higienicznego trybu życia, $w$ tym np. przebywanie dzieci na świeżym powietrzu, czystość pomieszczeń żłobkowych, dostateczna ilość bielizny, dobra kuchnia ${ }^{35}$. J. Bogdanowicz dowodził nawet, że dzieci żłobkowe są $\mathrm{o}$ wiele zdrowsze niż te chowane $\mathrm{w}$ domu. Jego zdaniem decydującą rolę odgrywała w tym pielęgniarka - „dusza żłobka” i lekarz ${ }^{36}$.

Już w pierwszej połowie XX w. w żłobkach zauważano również problemy natury psychologicznej dotyczące konsekwencji oddzielenia dzieci od ich rodziców. W prasie kobiecej pisano:

Praca w żłobku nie jest rzeczą łatwą. Słusznie trzymając się zasady, że nie należy odrywać dziecka zupełnie od matki, przyjmuje się tylko na czas pewien dzieci - drugą część dnia i noc

31 J. Bogdanowicz, Żłobki otwarte..., op. cit.

${ }^{32}$ H. Krahelska, Łódzki przemyst włókienniczy a ustawodawstwo pracy, Instytut Gospodarstwa Społecznego, Warszawa 1927, s. 32-34.

33 J. Zawadzka (oprac.), Przyczynki do spraw opieki nad dzieckiem robotniczem, Wydano z okazji dwuletniej rocznicy istnienia żłobków w Polskim Monopolu Tytoniowym, Warszawa 1930.

34 Ibidem, s. 23.

35 Ibidem, s. 23-27.

36 Ibidem. 
pozostawiając je matce w domu. Ta dwoistość opieki nad dzieckiem przy braku kultury i ciężkich warunkach mieszkaniowych i finansowych matek odbijają się ujemnie na dziecku ${ }^{37}$.

Przyczyn niekorzystnego rozwoju dzieci w żłobkach upatrywano niestety w samych matkach - w ich niekorzystnej sytuacji rodzinnej, niekonsekwencji w przyprowadzaniu do żłobka, błędach w opiece, pomijając czynnik fizycznego oddzielenia od matek. Przykładowo przy opisie żłobka przy zakładzie Monopolu Tytoniowego zauważano, że:

Na początku istnienia żłobka zgłaszano niejednokrotnie dzieci, jakby na próbę, to znaczy, że matka nie zdecydowana jeszcze na przynoszenie dziecka do żłobka, przynosiła je, przez kilka dni, aby zobaczyć, jak dziecko będzie się w żłobku czuło. Ponieważ dzieci poddawane tego rodzaju próbie były to przeważnie dzieci kilkumiesięczne, przyzwyczajone do ciągłego przebywania na ręku, do huśtania i stałego trzymania „smoczka” w buzi, nic więc dziwnego, że pozbawione tych „przyjemności” w obcem dla siebie otoczeniu przez pierwsze dni pobytu w żłobku płakały, a nawet wykazywały niekiedy nieznaczne ubytki w wadze; z punktu widzenia matki, próba w żłobku wypadała niekorzystnie i po jedno, względnie kilkodniowym, okresie próbnym matka taka przerywała przynoszenie ${ }^{38}$.

Panowało powszechne przekonanie, że matki są nieprzygotowane do rodzicielstwa, obwiniano je również za wysoką śmiertelność niemowląt. W literaturze obecny był ton nieufności wobec matek. Na łamach prasy kobiecej pisano:

wśród licznych frazesów życia codziennego niesłychanie rozpowszechniony jest ten, że każda kobieta, zostając matką, bez żadnej nauki nabywa umiejętność hodowania i wychowywania swojego dziecka. Jak dalece fałszywy jest ten pogląd, świadczy wielka śmiertelność niemowląt, zaś wśród dzieci utrzymywanych przy życiu - ileż spotykamy niedorodnych i charłaków! Jest absolutną nieprawdą jakoby młode matki opierały się jedynie na własnej intuicji. [...] $\mathrm{W}$ tem jednak leży cała trudność, że bez należytego przygotowania i wiedzy przy pielęgnacji dziecka każda przeciętna matka, błąkając się w labiryncie nieznanych sobie tajników i niespodzianek, popełnia cały szereg błędów, które narażają organizm dziecka na niepowetowane szkody. Gdy jest źle, wzywa się dopiero pomocy lekarza i leczy dziecko, zamiast zawczasu przez racjonalną pielęgnację zapobiegać niedomaganiom. A ileż to razy wezwany doraźnie lekarz nie ma już możności naprawić tego, co zostało zmarnowane ${ }^{39}$ ?

W żłobkach matka była postrzegana wręcz jako „czynnik” niekorzystny, zaburzający ich funkcjonowanie, wpływający negatywnie na efekty żywienia i opieki.

Jeżeli jednak zdrowie dzieci żłobkowych pozostawia nieraz wiele do życzenia - to dlatego, że trzeba się liczyć jeszcze z jednym potężnym czynnikiem, jakim jest matka. Podczas gdy żłobek zamknięty ma dziecko całkowicie pod swoją opieką - żłobek otwarty dzieli ją pół na pół z matką. O ile matki umieszczające dziecko w żłobku, nie będą współpracować z tą instytucją, nie ma żadnych szans na to, żeby żłobek, mógł owocnie pracować. [...] Zarówno jednak,

\footnotetext{
37 T.Z., op. cit., s. 5-6.

38 J. Jaroszewska, op. cit., s. 259.

39 S. Bujak-Boguska, Rady na troski matczyne, „Dziecko i Matka” 1926, nr 2, s. 1.
} 
wśród matek dzieci ślubnych, jak i nieślubnych, ma żłobek wiele kłopotu z narzuceniem swego autorytetu w wykonywaniu zaleceń i przepisów. Matka nie widząc cały dzień dziecka, po przyjściu do domu wylewa nań całą czułość, dając mu lub kupując tak niespodziewane rzeczy do jedzenia, jak serdelki, kiełbasę, ogórki itp. lub, podejrzewając instytucję, że „oszczędza” na dzieciach - przekarmia dziecko w domu. [...] Ta niekarność matek, nieufność, skłonność do okłamywania, sprowadza fakt, że bez wywiadu pielęgniarki, trudno polegać na podawanych danych, co utrudnia ocenę zdrowia dziecka przy przyjęciu ${ }^{40}$.

Z takimi poglądami wobec matek realizacja funkcji osobowych w żłobkach i współpraca $\mathrm{z}$ rodzicami jako pełnoprawnymi uczestnikami procesu wychowania i opieki była w tamtych czasach z zasady niemożliwa. Przyczyn takiego stosunku do matek należy upatrywać po pierwsze w braku dostępu do ówczesnej wiedzy psychologicznej dotyczącej rozwoju dzieci i znaczenia więzi w rodzinie, po drugie w nastawieniu na opiekę i zapobieganie chorobom z pominięciem wychowawczych aspektów działalności żłobków oraz przede wszystkim w poczuciu wyższości personelu wobec matek dzieci, które należały z reguły do najniższych i najuboższych warstw społecznych. Tymczasem pracownice żłobków były wykwalifikowanymi pielęgniarkami, które miały możliwość dokształcania się na trzymiesięczynych kursach dla opiekunek ${ }^{41}$.

J. Bogdanowicz podaje, że w żłobku dziennym prowadzonym przez Towarzystwo żłobków dla niemowląt w Warszawie przy ul. Puławskiej 33 znajduje się 30\% dzieci nieślubnych.

Na ogół stosunek matek do dzieci nieślubnych przedstawia wiele do życzenia, pomijając to, że matki te najczęściej są w bardzo ciężkich warunkach materialnych, sypiając w izbach, gdzie mieści się 10-14 osób, lub po prostu w norach, a w lecie wprost na ulicy; stan taki na pewno nie pomaga zdrowiu niemowląt. Poza tem wśród matek tych, występuje bardzo słabo instynkt macierzyński, częściej ukryta chęć pozbycia się dziecka (dwukrotnie w ciągu roku próby podrzucenia dziecka żłobkowi, w trzech przypadkach wyraźne stwierdzenie zaniedbania świadomego dziecka w przypadkach choroby) lub traktowanie w sposób zupełnie „dziki”, np. matka zabierając dziecko ze żłobka, szła na noc na dancing, do ogrodu publicznego, zostawiając roczne dziecko na trawie bez opieki po parę godzin, lub matki, które chodziły żebrać po południu i tylko na rano chciały przynosić dziecko do żłobka, by potem było im potrzebne dla lepszego efektu ${ }^{42}$.

Wielokrotnie w literaturze podkreślano, że „,materiał matek, który korzysta ze żłobka, jest najbardziej doświadczonym przez los (matki nieślubne 40\%, wdowy, matki licznych rodzin itd.) często wykolejonych lub doprowadzonych do zupełnej apatji i bezwoli"43. Do żłobków były przyjmowane dzieci - podrzutki będące w bardzo złym stanie fizycznym, toteż czasami żłobki pełniły rolę pogotowia opiekuńczego ${ }^{44}$.

\footnotetext{
40 J. Bogdanowicz, op. cit., s. 25.-27.

${ }^{41}$ Kronika krajowa, „Opieka nad Dzieckiem” 1931, nr 11-12, s. 397.

42 J. Bogdanowicz, op. cit., s. 23-27.

43 T.Z., op. cit., s. 5-6.

44 Kronika krajowa, „Opieka nad Dzieckiem” 1931, nr 11-12, s. 385.
} 
Już od początku istnienia żłobków, wobec wyżej opisanych problemów były one postrzegane jako instytucje kontrowersyjne ${ }^{45}$. Wobec konieczności pracy kobiet zrodziło się wówczas ogólne przekonanie o tych instytucjach jako będących „złem koniecznym” dla dzieci w nich przebywających. W pierwszych latach powstawania i rozwoju żłobków fabrycznych (1927-1928) matki-robotnice niechętnie i z nieufnością powierzały swoje dzieci opiece żłobkowej. Zaczęto więc zachęcać je do przynoszenia dzieci do żłobków poprzez rozmowy, wspólne oglądanie pomieszczeń żłobka, wskazywanie korzyści dla rozwoju dzieci ${ }^{46}$. Niestety ze strony matek częstym zachowaniem było „kwestionowanie najdrobniejszych rzeczy, wyszukiwanie dziury w całym, stałe groźby odebrania dziecka

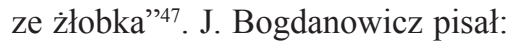

Ogólnie przyjęte zdanie o żłobku otwartem jako „złem koniecznem”, jest skutkiem wielu współdziałających przyczyn i niepowodzenia, jakie często spotyka wielkie wysiłki ze strony personelu instytucji, mają swe źródło w niskim poziomie zdrowotno-ekonomiczno-etycznym matek. Poprawienie tego stanu rzeczy poprzez reformy społeczne, będzie „idealnym” środkiem w walce ze śmiertelnością i chorobliwością dzieci.

Zdaniem autorki niniejszego artykułu, pomimo rozwoju teorii psychologicznych i pedagogicznych dotyczących rozwoju dziecka do lat trzech oraz zmian, jakim uległy żłobki w okresie późniejszym, pogląd ten jest obecny w środowisku rodziców i pedagogów do dziś i utrudnia on postrzeganie żłobka jako instytucji mogącej wspomagać rozwój dziecka.

Odpowiedzią na ówczesne problemy i potrzeby matek miały być Stacje Opieki nad Matką i Dzieckiem z Kuchniami Mlecznymi, które zakładano w Warszawie oraz w większych miastach Polski, np. w Częstochowie ${ }^{48}$. Pełniły one funkcję doradczą i kontrolną w zakresie żywienia, opieki i zdrowia małych dzieci. Zadaniem takich stacji była opieka dzienna nad dzieckiem zagrożonym różnymi chorobami. Podczas wizyt w poradniach lekarz, „wczuwając się w psychologię matki, pouczał ją, co jest dla dziecka wskazane, czego należy przestrzegać, a czego unikać”! Zadaniem stacji było „pouczanie” matek, gdyż - jak twierdzono:

większość matek nie umie obchodzić się z dzieckiem; pielęgniarka powinna pokazać namacalnie, jak należ się z dzieckiem obchodzić. Wszystko co jest możliwe powinno być przez nią zademonstrowane. Przewijanie, kąpiel, sposób karmienia ${ }^{49}$.

\footnotetext{
45 J. Bogdanowicz, op. cit., s. 23-27.

46 J. Zawadzka (oprac.), op. cit, s. 27.

${ }^{47}$ Ibidem.

${ }^{48}$ Kronika krajowa, „Opieka nad Dzieckiem” 1931, nr 5, s. 229.

49 R. Barański, Zadania i obowiązki pielęgniarki ma Stacji Opieki nad Matka i Dzieckiem, „Opieka nad Dzieckiem" 1927, nr 3, s. 150-154.
} 
Przy niektórych zakładach pracy z powodu braku lokali nie było możliwości otwarcia żłobka, wobec czego stworzono „opiekę lotną”, której celem była profilaktyka chorób oraz podniesienie jakości opieki nad niemowlęciem poprzez udzielanie wskazówek matkom. Opieka lotna przybrała formę odwiedzin pielęgniarki w domu niemowlęcia. Sprawdzała ona stan zdrowia dziecka kilka razy w tygodniu, ponadto raz w miesiącu dziecko przyprowadzone przez matkę było badane w poradni przez lekarza. Opieka lotna była zorganizowana m.in. w Warszawie, Wilnie, Białymstoku, Monasterzyskach, Winnikach, Poznaniu, Wodzisławiu ${ }^{50}$.

Podsumowując, można powiedzieć, że główna funkcja żłobków w okresie międzywojennym skupiała się na wypełnianiu ról: prozawodowej i opiekuńczej. Duże znaczenie miała również funkcja prozdrowotna - polegająca głównie na przestrzeganiu zasad higieny i właściwego odżywiania dzieci oraz izolacji dzieci zdrowych od chorych. Niewiele wiadomo o celach wychowawczych i edukacyjnych ówczesnych żłobków. Wydaje się, że zadania te realizowano bardziej w odniesieniu do matek niż do dzieci żłobkowych. J. Jaroszewska pisze, że zadaniem żłobka jest wychowanie matek: „w żłobku udziela się matkom wyjaśnień, rad, wskazówek, urządza pogadanki, kolportuje pisma wychowaniu dziecka poświęcone, w ten sposób odbywa się przenikanie wiedzy pedagogicznej"51. Rolę edukacyjną spełniały wówczas bardziej Stacje Opieki nad Matką i Dzieckiem, gdzie personel medyczny udzielał rad i wskazówek dotyczących wychowania małych dzieci, ale nie opiekował się nimi bezpośrednio ${ }^{52}$. Edukacji i wychowaniu dzieci mogły sprzyjać warunki stworzone we wzorcowych żłobkach w Łodzi i w Warszawie, gdzie dzieci miały do dyspozycji nowocześnie urządzone sale, a żłobki posiadały dziedzińce, na których dzieci bawiły się na świeżym powietrzu, miały do dyspozycji również zabawki i sprzęty dostosowane do ich możliwości rozwojowych ${ }^{53}$. W okresie międzywojnia $\mathrm{z}$ uwagi na negatywne postawy wobec matek dzieci przebywających w żłobku niemożliwa lub utrudniona była też realizacja funkcji osobowej, a współpraca personelu z matkami dzieci żłobkowych była nacechowana wzajemną nieufnością. Przyczyn mniejszego nastawienia na wychowanie i edukację dzieci w żłobkach należy upatrywać również w kontrowersyjnym charakterze tych placówek, problemach zdrowotnych niemowląt i małych dzieci oraz w braku wiedzy w zakresie psychologii dziecka i rodziny.

\section{Zakończenie}

Przeprowadzona na potrzeby niniejszego artykułu analiza funkcji żłobków w okresie od początku XX w. do wybuchu II wojny światowej pozwoliła odpowiedzieć na

\footnotetext{
${ }^{50}$ J. Zawadzka, op. cit, s. 15-16.

${ }^{51}$ J. Jaroszewska, op. cit., s. 268.

${ }_{52}$ R. Barański, Społeczne znaczenie Stacji Opieki nad Matka i Dzieckiem, „Opieka nad Dzieckiem” Warszawa 1930, nr 3, s. 118-120.

${ }^{53}$ J. Zawadzka, op. cit, s. 16-17.
} 
postawione we wstępie pytania badawcze. Problem główny dotyczył tego: Jakie można wyróżnić funkcje żłobków w ich historii mające na celu poprawę różnych obszarów funkcjonowania rodzin? Na podstawie literatury przedmiotu oraz badań własnych wyróżniono funkcję opiekuńczą, prozawodową, prozdrowotną, wychowawczą, edukacyjną i osobową. Głównym zadaniem pierwszych żłobków założonych jeszcze przed odzyskaniem przez Polskę niepodległości było umożliwienie matkom pracy w zakładach pracy $\mathrm{w}$ miastach uprzemysłowionych, które $\mathrm{z}$ powodu trudnej sytuacji materialnej zmuszone były do migrowania ze wsi i zostawiania swoich dzieci bez opieki na czas pracy. W dwudziestoleciu międzywojennym do funkcji opiekuńczej i prozawodowej doszła funkcja prozdrowotna, gdyż jednym ze społecznych priorytetów stała się walka z chorobami zakaźnymi i dużą śmiertelnością niemowląt. Pozostałe funkcje były co do zasady nieobecne w żłobkach. Czynnikami, które wpłynęły na powstanie pierwszych żłobków na polskich ziemiach, były industrializacja, migracja osób w wieku produkcyjnym do miast i wiążąca się z tym potrzeba zapewnienia opieki najmłodszym dzieciom podczas pracy rodziców. Przed odzyskaniem niepodległości żłobki były zakładane przez prywatne osoby lub Towarzystwa Dobroczynności, w okresie międzywojennym zaś instytucje te zaczęły podlegać Ministerstwu Pracy i Opieki Społecznej. Po I wojnie światowej z uwagi na pilne potrzeby opieki nad dziećmi osieroconymi i ubogimi opieka nad dzieckiem stała się sprawą państwową, a rozwój żłobków w niepodległej Polsce możliwy był dzięki prawodawstwu II Rzeczpospolitej, którego celem była ochrona macierzyństwa i objęcie troskliwą opieką matki i dziecka, między innymi poprzez tworzenie żłobków przyzakładowych. Ponadto zmiany w funkcjonowaniu żłobków uwarunkowane były rozwojem ówczesnej medycyny, w tym nastawieniem na higienę życia codziennego. Niniejszy artykuł przedstawia funkcje żłobków do wybuchu II wojny światowej, badania dotyczące zmian, jakie zaszły w organizacji i funkcjonowaniu żłobków w późniejszym czasie będą przedstawione w następnym artykule zatytułowanym Funkcje żłobków polskich od zakończenia II wojny światowej do początków XXI wieku na przykładzie żłobków lubelskich.

\section{Bibliografia}

\section{Źródła}

Barański R., Społeczne znaczenie Stacji Opieki nad Matka i Dzieckiem, „Opieka nad Dzieckiem” 1930, nr 3, s. 118-120.

Barański R., Zadania i obowiazki pielęgniarki na Stacji Opieki nad Matka i Dzieckiem, „Opieka nad Dzieckiem" 1927, nr 3, s. 150-154.

Bogdanowicz J., Żłobki fabryczne dla niemowląt, „Opieka nad Dzieckiem” 1927, nr 4, s. 193-197.

Bujak-Boguska S., Rady na troski matczyne, „Dziecko i Matka” 1926, nr 2, s. 1-2.

Garlicka Z., Żłobki dzienne dla niemowląt matek pracujacych, Drukarnia SIŁA, Warszawa 1927.

Jaroszewska J., 3 lata działalności żłobka fabrycznego przy Państwowej Fabryce Wyrobów Tytoniowych, „Opieka nad Dzieckiem” 1931, nr 7-8, s. 251-269. 
Jeszcze o losach opuszczonych dzieci, „Kronika Rodzinna” 1891, nr 22, s. 677.

Knichowiecki B., Pierwszy Miejski Dom Wychowawczy dla niemowlat w Lodzi, „Opieka nad Dzieckiem" 1931, nr 5, s. 217-228.

Kon W., Walka ze śmiertelnościa niemowląt w Lodzi, „Zdrowie” 1906, nr 11, s. 744-745.

Krahelska H., Lódzki przemyst włókienniczy a ustawodawstwo pracy, Instytut Gospodarstwa Społecznego, Warszawa 1927.

Kronika krajowa, „Opieka nad Dzieckiem”, Warszawa 1931, nr 5, s. 229.

Kronika krajowa, „Opieka nad Dzieckiem”, Warszawa 1931, nr 11-12, s. 385.

Kronika krajowa, „Opieka nad Dzieckiem”, Warszawa 1931, nr 11-12, s. 397.

Markiewicz S., Sprawa dzieci opuszczonych, „Ateneum” 1890, nr 6, t. II, s. 416-417.

Michałowicz M., Ksztatćmy się, „Opieka nad Dzieckiem” 1930, R. VIII, nr 3, s. 124.

T.Z., Żłobek otwarty, „Dziecko i Matka” 1926, nr 13, s. 5-6.

Zawadzka J. (oprac.), Przyczynki do spraw opieki nad dzieckiem robotniczem, Wydano z okazji dwuletniej rocznicy istnienia żłobków w Polskim Monopolu Tytoniowym, Warszawa 1930.

\section{Akty prawne}

Rozporządzenie Ministra Pracy i Opieki Społecznej z dnia 11 marca 1927 r. w sprawie urządzenia i utrzymania żłobków dla niemowląt w zakładach pracy, Dz.U. 1927, nr 32, poz. 293.

Ustawa z dnia 16 sierpnia 1923 r. o opiece społecznej, Dz.U. 1923, nr 92, poz. 726.

Ustawa z dnia 2 lipca 1924 r. w przedmiocie pracy młodocianych i kobiet, Dz.U. 1924, nr 65, poz. 636.

Ustawa z dnia 4 lutego 2011 r. o opiece nad dziećmi wieku do lat trzech, Dz.U. 2011, nr 45, poz. 235.

\section{Opracowania}

Adamski F., Rodzina. Funkcje rodziny, w: Encyklopedia pedagogiczna XXI wieku, red. T. Pilch, Wyd. Akademickie „Żak” Warszawa 2006, s. 309.

Balcerek M., Rozwój opieki nad dzieckiem w Polsce w latach 1918-1939, PWN, Warszawa 1978.

Bołdyrew A., Żłobki i stacje „Kropla Mleka” jako placówki wspierajace ubogie rodziny w Królestwie Polskim na przełomie XIX i XX wieku, „Wychowanie w Rodzinie” 2016, t. XIV, z. 2, s. $103-119$.

Drabik L. Sobol E., Słownik języka polskiego. A-Q, PWN, Warszawa 2007, s. 186.

Golde Z., Żłobek. Organizacja i prowadzenie, PZWL, Warszawa 1956.

Pilch T., Bauman T., Zasady badań pedagogicznych. Strategie ilościowe i jakościowe, Wyd. Ak. „Żak”, Warszawa 2001.

Topolski J., Metodologia historii, PWN, Warszawa 1984.

Wnęk J., Dziecko w polskiej literaturze naukowej 1918-1939, Oficyna Wydawnicza ASPRA-JR, Warszawa 2012. 